\title{
The impact of monopolism on the stability of economic development in the conditions of globalization
}

\author{
Tatiana Kotcofana ${ }^{1, *}$, Armen Altunyan ${ }^{1}$, Viktoria Bazzhina ${ }^{1}$ \\ ${ }^{1}$ Saint-Petersburg State University 7-9, Universitetskaya nab., St. Petersburg, 199034, Russian \\ Federation
}

\begin{abstract}
The article discusses the impact of the level of monopolization of markets on the sustainability of economic development and, above all, on the development of inflationary processes in terms of the reproduction approach in the global economy. The purpose of the article is to show the key role of monopolism in the genesis of inflation and its negative impact on the sustainability of economic development. The article uses a reproductive approach to the analysis of economic phenomena and processes. Using dialectical materialistic and concrete historical methods, it is shown how monopolism contributes to the development of inflation at all stages of the reproductive process. So, in Russia throughout the entire period of reforms, with the exception of individual years, the producer price index of industrial products grew faster than the consumer price index, and prices in more monopolized industries grew much faster than in less monopolized ones, which confirms the important the role of monopolies in the unwinding of the inflationary process.
\end{abstract}

\section{Introduction}

The high degree of monopolization of the Russian economy is a well-known fact not only in scientific circles, but also widely discussed in the press. Much has been said and written about its causes and consequences [1]. However, let's try to look at this fact from a new angle from the point of view of its impact on the possibility of Russia's entry into the global economy and, most importantly - effective existence in this tough environment [2].

Despite the ambiguity of the definition of the category "globalization" in modern economic theory [3], most authors agree that it carries not only a positive potential for the world community, but also increases the risks and threats to its development [4]. The processes of globalization contribute to the intensification of contradictions in the development of the world community [5], growth of interdependence of national economies [6], increasing their dependence on a relatively small number of transnational corporations [7]. Modern globalization is characterized by widespread financialization of the economy, while the financial sector does not perform the function of optimal placement of capital and risks and contributes to the further development of "Casino Finance". It enslaves society and subordinates to its logic the entire economy, which therefore ceases to play its role and

* Corresponding author: t.kotsofana@spbu.ru 
contribute to public welfare $[8,9]$. According to the study [10] income inequality caused by Finance (financial development, financial liberalization, and banking crises) is associated with greater income redistribution than inequality caused by other factors [11]. One of the negative results of globalization is the dominance of developed countries and their largest companies to the detriment of the national interests of the less developed, as exemplified by Russia. Thus, monopolistic tendencies, which are typical for Russia, are amplified by the influence of global corporations [12].

One of the problems that has always been in the focus of attention of the Russian authorities is inflation, the regulation of which for many years has been one of the priorities of economic, primarily monetary policy [13]. It is for the declared fight against inflation that there is a permanent restriction of the money supply by the Bank of Russia, while in most developed countries, governments and central banks provide systematic support to their economies in the form of financial injections and the provision of state guarantees [14]. To what extent are such measures justified? The answer to this question seems to us to be closely related to the role of monopolistic structures in the development of inflationary processes.

\section{The role of monopolies in the development of inflation at different stages of the reproductive process}

\subsection{Research methods}

As the methodological basis of the study, we use the dialectical materialistic and concrete historical method. On the one hand, the dialectical method allows us to know the essence of the processes under consideration in the most adequate reflection of their dynamic integrity, on the other hand, any theoretical research should be supported by historical practice and statistical data. Therefore, having comprehended the mechanisms of the influence of monopolies on price stability from a theoretical point of view, it is necessary to turn to specific statistical data confirming this influence.

In the framework of dialectical materialistic logic, it is most appropriate to use a reproductive approach to the analysis of the causes of inflation, so we show the inflationary impact of monopoly on the economy at different stages of the reproductive process.

\subsection{Production stage}

All the variety of price-forming factors is divided into two large groups: factors affecting the value of the goods (primary), and factors that deviate the price of the goods from the value, that is, contributing to the implementation of redistributive processes between social classes, industries and geographical regions (secondary and derivative) [15]. In the analysis of factors affecting the value, the main attention is focused on the production sphere, and in the analysis of factors that deviate the price from the value - on the sphere of implementation (exchange). Another thing is that the boundary between these factors is not always clear, since the close relationship of the areas under consideration sometimes means that these factors describe the same event, but from different points of view.

Traditionally, the monopolization of markets is seen as a factor that deviates the price from the value and contributes to the monopolist obtaining super profits. That's fair. But, on the other hand, under monopoly conditions, the producer does not receive sufficient incentives to reduce the cost of its products. If new technologies are introduced in the context of free competition to reduce the cost of production, each of the competing producers-sellers seeks to introduce these innovations first in order to either gain additional profit for some time due to the difference between the average market price and the reduced costs, or reduce the price and thus increase sales of their products. The cost of implementing the new technology will eventually pay off. If a manufacturer abandons resource-saving technologies, 
it risks incurring losses, as one of the competitors will certainly use them, and sooner or later all will have to implement them, but without additional benefits from their implementation. The monopolist has no reason to introduce new technologies, increase sales, reduce costs. Monopolies are able to make super profits by raising prices, limiting the supply of their products, restraining the growth of production capacity, inhibiting the introduction of new, cheaper products, directing technical research to the development of such products and technologies that not only do not reduce the cost, but sometimes lead to higher prices of products. Thus, the monopolization of markets is not only the reason for the separation of prices from the value of goods, but also the cause of the real rise in the cost of social production.

\subsection{Distribution stage}

If at the stage of production inflation is generated by a real rise in the cost of production, then at the stage of distribution the causes of inflation are not just economic, but socio-economic nature. The nature of distribution inflation is rooted in social conflict over the distribution of social product between different social groups and strata of society [16]. The socio-economic conditions of this conflict are the unequal opportunities of different economic agents, social groups and countries in access to the produced national product, due to the existing economic and institutional structures. This basic source is a necessary but insufficient condition for the existence of inflation. Inflation from its potential form is transformed into real only under certain conditions, in the presence of a whole set of factors operating in the economic sphere. One of these factors is the monopoly in the markets.

Differences in the impact of monopolistic forces on various economic sectors are one of the economic prerequisites for the violation of the cost structure, as an immediate cause of inflation. By holding economic power in various sectors, pursuing the goal of preserving the profitability of production, monopolies objectively deepen violations of cost and price proportions in the entire system of reproductive relations. There is a law of price proportions, according to which the ratio between the values of the prices of all goods must correspond to the ratio of their values. If the value of an item has changed and the price has remained the same, the item will be sold at a price not corresponding to the value. The goods owner will receive either additional income at the expense of other producers (if the price is higher than the cost), or will be at a loss. But in conditions of free competition, this cannot continue indefinitely: due to inter-sectoral competition and the overflow of capital, price proportions will be restored in accordance with cost proportions. The goods owner will receive either additional income at the expense of other producers (if the price is higher than the cost), or will be at a loss. But in conditions of free competition, this cannot continue indefinitely: due to inter-sectoral competition and the overflow of capital, price proportions will be restored in accordance with cost proportions. The law of price proportions operates differently in the conditions of monopolization of the market. Modern chronic inflation is largely due to the emergence and spread of a monopoly on pricing in all civilized countries. Inflationary price increases can be associated with keeping prices stable or even raising them, despite the decline in value. If the value of an enterprise's goods declines as a result of productivity growth, and the price does not change, the price becomes higher than the value, which entails obtaining a monopoly superprofit equal to the difference between the monopolistically high price (even if its absolute value has not changed) and the minimum price that would have developed in conditions of free competition (equal value). This monopoly superprofit is a deduction from the labor of the owners of other goods. Consequently, they sell their goods at a price that is lower than the cost. The law of price proportions requires the restoration of the correct ratio of these values: if the prices of goods, the value of which has decreased, have not changed, the prices of other goods change - they necessarily increase. This increase will 
occur as long as the proportions between prices do not correspond to the proportions between the values of all goods. Inflation ends when the ratio of prices comes into line with the values of their values, and the incomes of normally operating enterprises in different industries are equalized. But this will not happen soon, as monopolies will seek to retain the previously achieved advantage over others in the assignment of monopolistically high profits. They, like others, will raise the prices of their goods, and they will have both formal grounds for doing so (the very fact of inflation in the country) and formal justifications (the increase in the cost of purchased factors of production due to the General increase in prices).

\subsection{Exchange stage}

In the area of exchange, the role of monopolies in the development of inflation is obvious and consists in the ability to set an inflated price for their products compared to the price of a competitive market. In the context of the reduction of effective consumer demand, the first reaction of a competitive company will be a decrease in prices, and the monopolist is likely to reduce production with the preservation or even increase in previous prices for its products. This reaction is objectively due to the macroeconomic mechanism of the monopolist's behavior in the market of goods. The ratchet effect observed in the modern economy in all sectors is primarily due to its high degree of monopolization. An important role in the unwinding of the inflation flywheel at the exchange stage is played by the broad development of intermediary structures. According to some estimates, the share of intermediaries in final prices of consumer goods is $60-70 \%$ [17]. There is a danger of monopolization of intermediary activity, which is the worst form of monopolism, because, unlike the monopoly of the producer, it does not even potentially contain the possibility of reducing production costs due to positive economies of scale.

\subsection{Consumption stage}

As for the inflationary influence of monopolies at the stage of consumption of the created social product, there is no such direct connection as at the other three stages. However, monopolies in the goods markets are indirectly linked to monopolies in the factor markets, especially in the labour market. The dictatorship of employers in the labor markets means low wages, which significantly reduces the possibility of economic development in terms of both consumer demand and investment. Magalhães et al. in their study [18] showed that the greater the concentration, the more profit is distributed in the form of dividends, and the greater the share of income paid to capital. On the one hand, low incomes do not allow to show effective demand for goods and services, which acts as a refund to producers when selling directly to the consumer or traders (retail trade), who then use the funds received (minus taxes) to purchase goods from producers and wholesalers, to cover their costs, and the remaining profit - to expand their business, accumulation. On the other hand, low incomes mean that the main source of investment financing - household savings in the form of Bank deposits and securities - is not fully operational. Kaigorodova et al. showed in their study [19] that in Russia there is a tendency to increase the amount of money remaining outside the sphere of consumption or investment. There is a shortage of means of payment in enterprises, which leads to a rise in the cost of credit and to an overall increase in costs. In a monopolized market, this inevitably means reduced production and higher prices.

Thus, we have seen that the monopolization of markets can really have a significant impact on prices at all four stages of the reproduction process. The theory has been repeatedly confirmed by empirical data, which is easy to verify, including the example of the Russian economy. 


\subsection{Inflationary processes in the Russian economy: the role of monopolies}

Throughout the twentieth century, monopoly in one form or another influenced the price dynamics in the Russian economy, even in those years when other factors were decisive in the development of inflation. Forms of monopolization has varied from private syndicates in the beginning of the century through the state supermonopolies in the Soviet era to the modern "private and monopolized" economy. Natural monopolies play a very important, though not exhaustive, role in the modern Russian economy. However, the monopolization of the Russian market cannot be reduced to the problem of regulating natural monopolies, being by its nature more extensive and more profound.

Throughout the thirty years of reforms, except for certain years, the index of producer prices of industrial products grew at a faster pace compared to the consumer price index, while prices in the more monopolized industries have grown much faster than in a less monopolized (See Table 1 and 2).

Table 1. The ratio of the rate of growth of consumer prices (CPI) and industrial producer prices (PPI) in $1991-2018$

\begin{tabular}{|c|c|c|c|c|c|c|c|c|c|c|c|}
\hline & 1991 & 1995 & 1996 & 1997 & 1998 & 1999 & 2000 & 2001 & 2002 & 2003 & 2004 \\
\hline CPI & 2600 & 230 & 121,8 & 111,0 & 184,4 & 136,5 & 120,2 & 118,6 & 115,1 & 112,0 & 111,7 \\
\hline PPI & 3400 & 270 & 125,6 & 107,5 & 123,2 & 167,3 & 131,6 & 110,7 & 117,1 & 113,1 & 128,3 \\
\hline & 2005 & 2006 & 2007 & 2008 & 2009 & 2010 & 2011 & 2012 & 2013 & 2014 & 2015 \\
\hline CPI & 110,9 & 109,0 & 111,9 & 113,3 & 108,8 & 108,8 & 106,1 & 106,6 & 106,5 & 111,4 & 112,9 \\
\hline PPI & 113,4 & 110,4 & 125,1 & 93,0 & 113,9 & 116,7 & 112,0 & 105,1 & 103,5 & 106,3 & 112,1 \\
\hline & 2016 & 2017 & 2018 & & & & & & & & \\
\hline CPI & 105,4 & 102,5 & 104,3 & & & & & & & & \\
\hline PPI & 107,5 & 108,4 & 111,7 & & & & & & & & \\
\hline
\end{tabular}

Source: Federal state statistics service of Russia

http://www.gks.ru/wps/wcm/connect/rosstat_main/rosstat/ru/statistics/tariffs/\#

Table 2. Indices of relative prices for products of Russian industries in 2012 compared to 1990, times

\begin{tabular}{|l|c|}
\hline \multicolumn{1}{|c|}{ Industry } & Index \\
\hline Industry on average & 1,00 \\
\hline Fuel industry & 3,87 \\
\hline Ferrous metallurgy & 2,35 \\
\hline Nonferrous metallurgy & 1,51 \\
\hline Electroenergetics & 1,48 \\
\hline Food industry & 0,94 \\
\hline Building material & 0,69 \\
\hline Chemical & 0,68 \\
\hline Petrochemical & 0,66 \\
\hline Engineering & 0,57 \\
\hline Forestry, woodworking and cellulose and paper industry & 0,43 \\
\hline Light industry & 0,28 \\
\hline
\end{tabular}

Source: [20]

\section{Conclusion}

The data presented indicate that it is pointless to fight inflation in Russia with monetary methods. Of course, the fact that Russian inflation is primarily supply-side inflation has long been recognized by most economists, and in itself is not direct evidence that the main cause of inflation in the Russian economy is the high degree of its monopolization. However, the 
data presented illustrate at least not the last role of monopoly in the development of inflation processes, at least in the Russian economy. Further justification of this role and its quantification require further theoretical and empirical, including statistical, research and analysis.

The article was prepared with the financial support of the Russian Foundation for Basic Research (project 19-010-00751 \19).

\section{References}

1. K. Falkowski, Trade interdependence between Russia vs. the European Union and China within the context of the competitiveness of the Russian economy, Equilibrium. Quarterly Journal of Economics and Economic Policy 13, 667-687 (2018)

2. V. Fanelli, A.K. Ryden, Pricing a swing contract in a gas sale company, Economics, Management, and Financial Markets 13, 40-55 (2018)

3. M. Nový , The impact of globalization on the price elasticity of demand. Globalization and Its Socio-Economic Consequences, 538-545, Zilina, Slovakia, (2015)

4. V. Šoltés, S. Štofko,. The impact of population movement on security in the age of globalization. Globalization and Its Socio-Economic Consequences, 773-778, Zilina, Slovakia, (2015)

5. M. Tokárová, Selected problems of competitiveness measuring in conditions of globalization. Globalization and Its Socio-Economic Consequences, 800-809, Zilina, Slovakia , (2015).

6. K. Kramárová, K. Valášková, Globalization and transfer pricing: brief analysis of the legislation in the Slovak republic. Globalization and Its Socio-Economic Consequences, 353-361, Zilina, Slovakia, (2015)

7. A. Harumová. Multinationals as a part of globalization. Globalization and Its SocioEconomic Consequences, 192-198, Zilina, Slovakia , (2015)

8. N. Bernards The poverty of fintech? Psychometrics, credit infrastructures, and the limits of financialization. Review of International Political Economy (to be published)

9. L. C. Bresser-Pereira, Secular stagnation, low growth, and financial instability. International Journal of Political Economy. 48 (1), 21-48, (2019)

10. A.Van Velthoven, J. De Haan, JE. Sturm, Finance, income inequality and income redistribution. Applied Economics Letters, 26 (14), 1202-1209, (2019)

11. L. Ionescu, Political power, local government, and firm performance: Evidence from the current anti-corruption enforcement in China, Journal of Self-Governance and Management Economics 6, 119-124 (2018)

12. A. Cieślik, L. Wincenciak, Intra-industry trade in differentiated and homogenous commodities: Brander and Krugman models unified, Equilibrium. Quarterly Journal of Economics and Economic Policy 13, 29-53 (2018)

13. S.K. Singh, D. Tripati Rao, Is monetary policy symmetrical in its effect on sectoral output?, Economics, Management, and Financial Markets 13, 11-31 (2018)

14. A. Ruščáková,. The European sovereign debt crisis: the result of the financial globalisation and of the system failures of global economic and political order. Globalization and Its Socio-Economic Consequences, 617-626, Zilina, Slovakia, (2015)

15. A. Davidov, SSHA v mirovykh tsenoobrazovatel'nykh protsessakh, Moscow, (1990) 
16. A. Protasov, Tsiklicheskaya dinamika inflyatsii v ekonomike SSSR: istoricheskiye trendy i raspredelitel'nyye konflikty. Problemy sovremennoy ekonomiki, 2, 73-78, (2015)

17. R. Belousov, A. Belousov, D. Belousov, Inflyatsiya: faktory, mekhanizm, strategiya preodoleniya. Ekonomist, 4, 46, (1996)

18. M. Magalhães, T. Sequeira, O. Afonso, Industry concentration and wage inequality: a directed technical change approach. Open Economies Review, 30, (3), 457-481, (2019)

19. G. N. Kaigorodova, A. A. Mustafina, D. P. Alyakina, G. Kh. Pyrkova, I. R. Abduzalimov, Peculiarities of forming the savings by the Russian population in modern conditions. Revista San Gregorio, 25, 21-27. Special Issue: SI. (2018)

20. A. Kornev, Proizvodstvennyy potentsial Rossii: povysheniye konkurentosposobnosti obrabatyvayushchey promyshlennosti. Problemy prognozirovaniya, 5, 53-69, (2014) 